\title{
Development of low-cost reflective plate thermal energy absorber systems for application in South Africa
}

\author{
Fanos Mutizhongo ${ }^{1,2}$, Lukas W. Snyman ${ }^{* 1}$ (D), Kevin Jalet ${ }^{2}$ \\ 1. Institute for Nanotechnology and Water Sustainability, College for Science Engineering and Technology, \\ University of South Africa \\ 2. Department of Electrical Engineering, College for Science Engineering and Technology, University of South \\ Africa, Florida, Johannesburg, South Africa
}

\begin{abstract}
An innovative solar heat collector system was developed from low-cost materials by applying innovative design technology and using adaptive technologies. The system design entails placing long black polymer pipes connected in series circulation, mounted and positioned in grooves of inverted box rib galvanised steel plating. The grooves reflect and focus the incident rays on the centre piping, concentrating incident sun rays on the black piping and increasing the absorption of thermal energy in the piping filled with circulating water. The circulation of the water is facilitated by a direct-current solar-driven pump powered by a small photovoltaic panel. The thermal energy as collected is stored in a standard household geyser tank. A $3 \times 4 \mathrm{~m}$ heat absorber of this type collects approximately $10 \mathrm{kWh}$ of energy per day. The estimated cost of the system, considering the capital outlay over an expected ten-year life cycle for the product was estimated at R0.25 per $\mathrm{kWh}$. This pricing competes extremely favourably with the general cost of grid electricity in South Africa for medium-sized households, which is of the order of R2 per $\mathrm{kWh}$ up to $1000 \mathrm{kWh}$ per month, including taxes. With an estimated electricity cost escalation of above 5\% every year, the ten-year saving for a household using this prototype can be approximately R200 000. The technology and designs developed through the study can create many new business opportunities in South Africa in both urban and rural environments, through manufacturing, installing, repairing, and maintaining the systems.
\end{abstract}

Keywords: solar energy, solar water heat collector, thermal energy, heat transfer, solar irradiation; thermal efficiency, heat transfer fluid

\section{Highlights:}

- Development of low-cost thermal energy absorbers for South Africa and Africa

- Harvesting of solar thermal energy

- Application in different formats, roof panels, aesthetic panels

- Labour intensive job opportunity creation possibilities

- Business creation under established intellectual property

Journal of Energy in Southern Africa 32(3): 41-56

DOI: https://dx.doi.org/10.17159/2413-3051/2021/v32i3a8044

Published by the University of Cape Town ISSN: 2413-3051 https://journals.assaf.org.za/jesa

This work is licensed under a Creative Commons Attribution-ShareAlike 4.0 International Licence

Sponsored by the Department of Science and Innovation

Corresponding author: Tel.: +27 (0)11 471 2320; email: snymalw@unisa.ac.za 


\section{Introduction}

Eskom's increasing electricity tariffs and inconsistencies in power supply result in South Africans looking for alternative sources of energy, such as solar energy. South Africa is among the countries with the best solar energy resources in the world and enjoys the best sunshine throughout the year (Ward, 2002; Solar GIS, 2017). Figure 1 gives some technical data in this regard and particularly indicates an average of about $6 \mathrm{kWh}$ per square metre per day (or approximately $2000 \mathrm{kWh}$ per square metre per year) for most parts of South Africa.

Solar water heating systems (SWHSs) comprise various technologies that are used in South Africa. The domestic SWHS designs commonly available on the local market are natural circulation, forced circulation and evacuated vacuum tube collectors. This section reviews domestic SWHS characteristics, efficiencies and cost aspects, as provided by suppliers in South Africa. UberSolar and KwikSol, also known as Kwikot, as two of the commonly used systems, were used for the analyses of existing domestic SWHS technology in terms of cost, solar heat energy collected per day (kWh/day), payback time, and savings over a period of ten years.

Natural circulation systems have a water storage tank horizontally mounted immediately above the solar collectors on the roof. No pumping is required as the hot water naturally rises into the tank through thermosiphon flow. A $150 \mathrm{~L}$ unit would cost R21 500, with deemed stored solar heat energy of $5.50 \mathrm{kWh} /$ day, energy cost of R1.08 per kWh, payback time of 40 months, and a ten-year saving of R86 242 (UberSolar, 2018; One Energy, 2019).

Forced circulation systems normally use a pump to circulate the Heat Transfer Fluid (HTF) in either direct or indirect water heating systems between the tank and the collectors. The storage tank is usually ground or floor mounted and is below the level of the collectors. A $150 \mathrm{~L}$ unit would cost R24 500, with deemed stored solar heat energy of $7.60 \mathrm{kWh} /$ day, energy cost of R0.89 per kWh, payback time of 33 months, and a ten-year saving of R88 700 (UberSolar, 2018).

Evacuated vacuum tube collectors are more efficient than the former, but have a complex design. A $150 \mathrm{~L}$ unit would cost R23 500, with deemed stored solar heat energy of $6.90 \mathrm{kWh} /$ day, energy cost of R0.94 per kWh, payback time of 30 months, and a ten-year saving of R96 332 (UberSolar, 2018).

A test carried out by the CSIR (2016) showed that $40-60 \%$ of a household's electricity consumption is used for heating water. Using a solar energy geyser in a household would mean great electrical energy saving for South African households, in the order of $\approx 60 \%$ of the electricity bill.

The general perception is that the South African populace does not have the financial capacity to invest in these systems. Low-income communities are simply too poor in financial capital to be able to afford the purchase of solar water heaters. This inability is attributed to the high initial cost price and

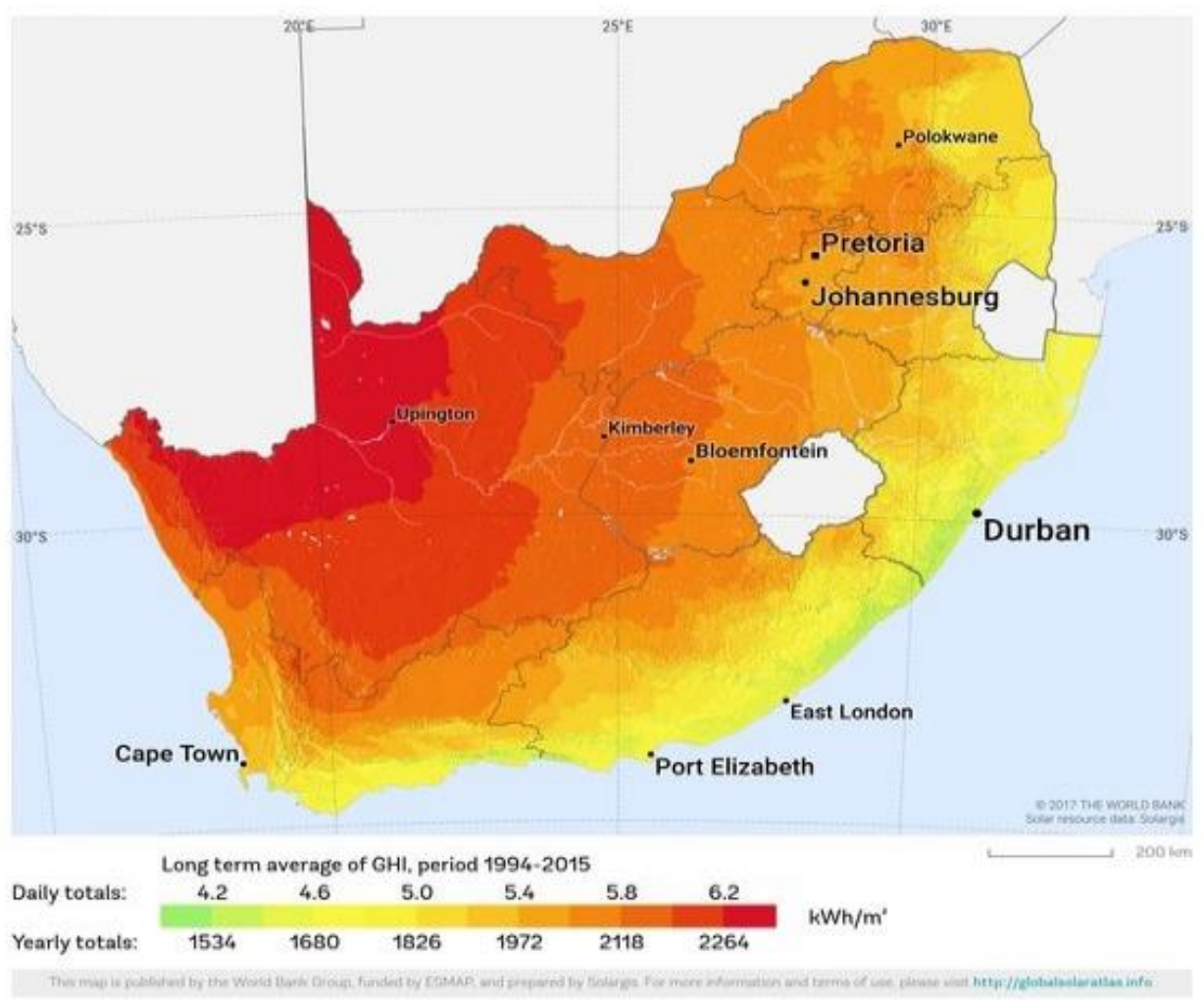

Figure 1: Average global horizontal irradiation for South Africa, period 1994-2015 (Solar GIS, 2017). 
installation costs of these systems. We have developed specialized photovoltaic solar energy collection systems with adaptive technologies (impedance matching and tilting panels to follow the sun) and compared the cost efficiency of these systems with thermal energy collection systems (Mvili-Gampio and Snyman, 2018). The developers have also focused on design and efficiency aspects associated with a low-cost heat exchanger that could be installed in a conventional geyser together with electrical heating, but prioritised solar energy storage (Twite and Snyman, 2019). This system isolates the high-pressure part of a geyser from a low-pressure solar energy collection and circulation part, thus increasing the reliability of the system. This study further focused on the efficiency of heat transfer with copper coils in such solar geyser systems.

This article reports on a new solar water grid based absorber system which was developed using a reflector based back plate and with an array of polyethylene black piping positioned at a distance elevated above the reflector plate, which is an elaboration and further development on our previous developed system. The aim of the study was to develop an extremely low-cost but still efficient absorber system that can have diverse and new mindshift and penetrating applications, both sub-urban and rural. The system was developed with an aim of being a more aesthetic system than the large vertical metal structures often encountered in the South African market, and that the product could compete with other such systems on the market in South Africa, and also in Africa.

\section{Design of a low-cost solar thermal energy absorber and storage system \\ 2.1 System design and components}

The system design, as schematically illustrated in Figure 2, consisted of two main parts, A and B. Part
A was a large-area, low-cost solar heat absorber, comprising of a long plastic polymer pipeline system connected in a series and laid slightly elevated on top of inverted box rib (IBR) galvanised steel plating. The plating had a high reflection coefficient of about 0,6 and reflected and redirected solar heat rays from the sun back to the pipe with increased absorption of heat energy in the piping. Part B was a retrofitted electric geyser with the electric element removed and replaced with a copper coil heat exchanger. A 150-litre geyser tank was chosen, capable of serving a family of four to five people with hot water for general household use.

A small solar photovoltaic (PV) panel and a DC electric pump circulated the heat transfer fluid around a low-pressure closed loop, allowing heat collected by the collector pipes to be transferred to the water in the geyser through a copper coil heat exchanger (CHE) system. Water was preferred as the heat transfer fluid because of its general availability and very favourable comparison with other heat transfer fluids available. By using a CHE system, the low-pressure HTF loop and heat transfer system were separated from the high-pressure water circulation tank system, that comes from the incoming line, and also supplied high pressure hot water to the household. This system increased the long-term reliability of the system, since it avoids high water pressure entering the fragile heat collection part of the system, preventing catastrophic leaking and failure of the system. It also avoids longterm fouling of the heat collection system by contaminants in the external water flows. An electronic micro-processor was used to control and regulate the electric pump flow rate and ensure maximum heat transfer to the geyser / heat reservoir. The system was developed at the Florida campus of the University of South Africa.

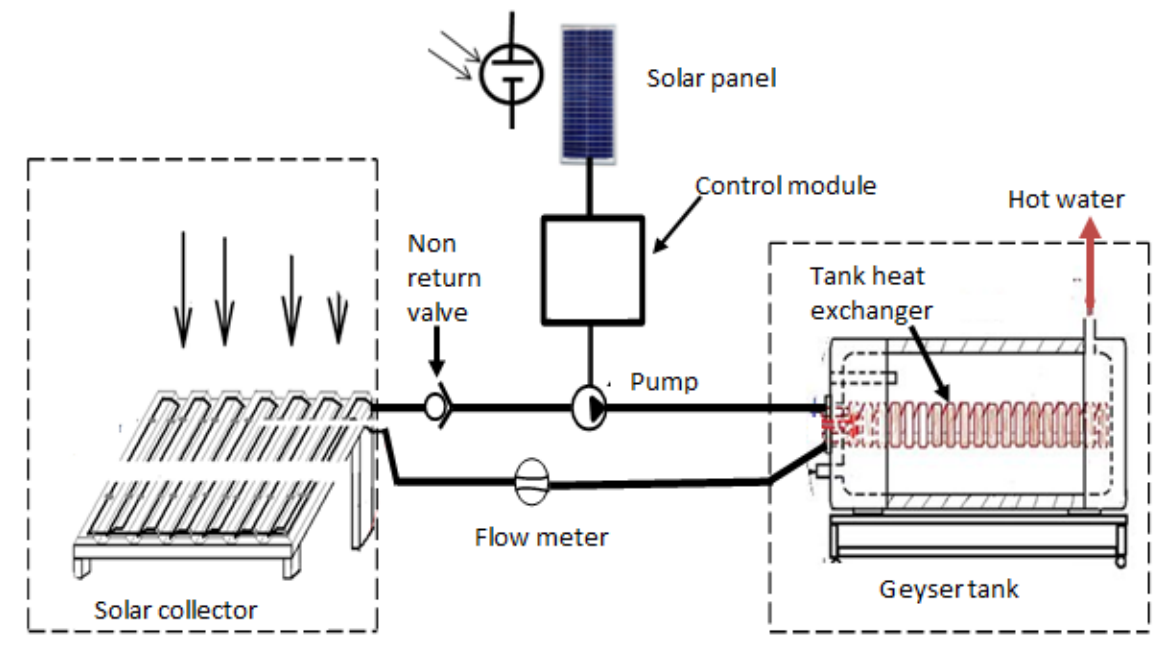

A

Figure 2: Schematic diagram of the-cost thermal energy absorber and storage system. 


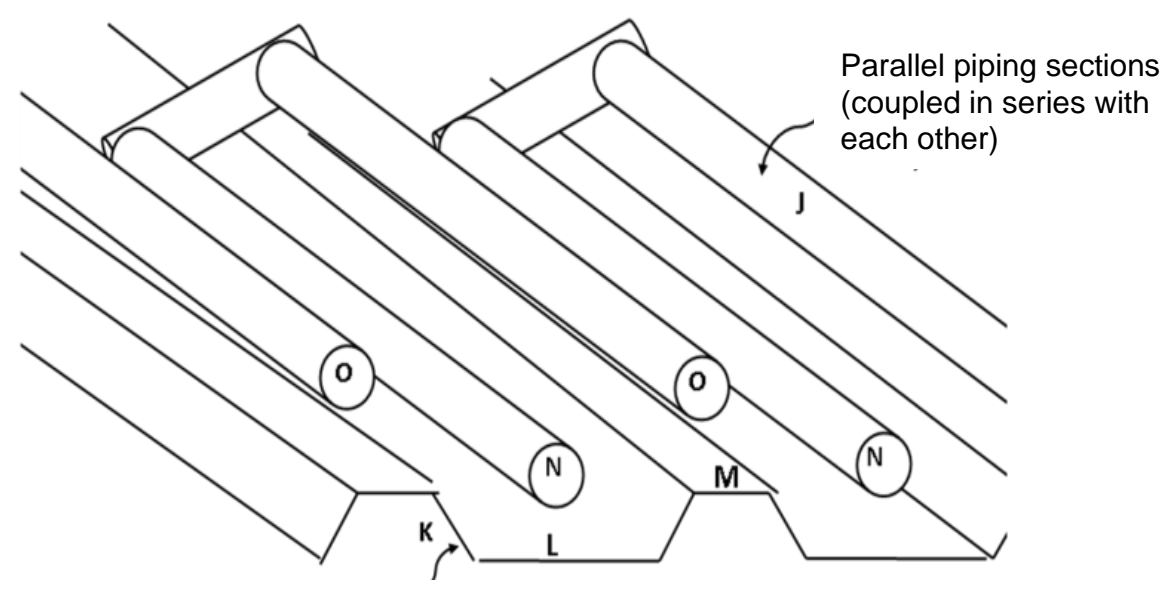

Reflective surface (could be part of existina roof)

Figure 3: Schematic illustration of the low-cost inverted box rib sheeting and elevated black piping design. The groove, $\mathrm{L}$, in the sheeting directs and focuses the incident radiation on to the black piping, $\mathrm{O}$ and $\mathrm{N}$.

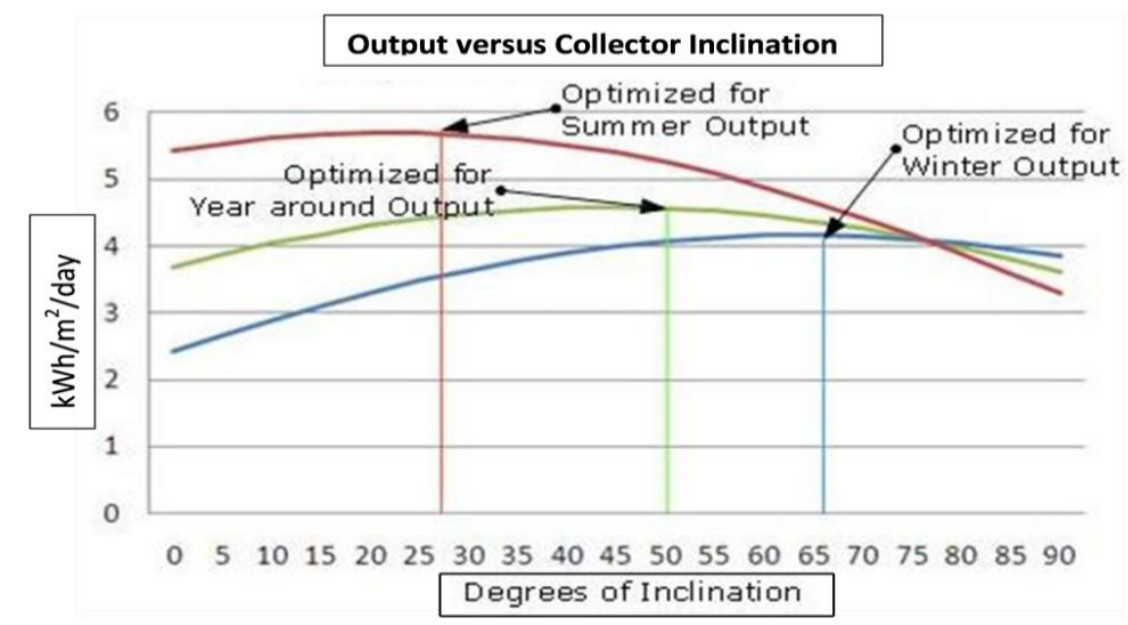

Figure 4: Output versus collector inclination, Pretoria (Northern Lights, 2014).

\subsection{Conceptual design of the large-area thermal absorber grid}

A key component of the low-cost, large-area thermal energy collection system was the design of its absorber grid. The aim was to capture the largest amount of solar thermal energy over a large area, with materials of the lowest possible cost. A simple design was chosen using a reflector plate made from IBR standard roof sheeting and fitted with a series of black absorber piping on top of the backplate sheet. The grooves in the IBR sheeting act as natural focusing of solar radiation on concentrated regions above the roof, depending on the position of the sun and its trajectory path during the day. The conceptual design is schematically illustrated in Figure 3.

It was envisaged that this design would lead to an innovative design that could largely outperform other designs at present on the South African market, in terms of cost and efficiency. The design would also be much more aesthetically pleasing than the large, mostly vertical, pedestal-like metal structures currently seen on the roofs of South African households. Also, the absorber concept could find many other applications; the absorber units could even be placed vertically on sun-facing walls of households, or on heat-absorbing stone, tile or paved structures.

\subsection{The collector orientation and tilt angle}

In general, the collector should face the direction of the sun. For the best annual average performance, the absorber top surface should be tilted at an angle equal to the geographical latitude (Northern Lights, 2014). For example, Pretoria's latitude is $28^{0}$, so the solar collector tilt angle and orientation should be $28^{0}$ facing north for optimum harvesting of solar heat throughout the four seasons of the year (Northern Lights 2014). Figure 4 shows the heat collection capability for various tilt angels from the earth surface toward the equator as determined by the company Northern Lights (2014). The green curve shows optimised year-around output results for a tilt angle of about $50^{\circ}$. 
Table 1: Properties of common tubing materials (EMCO Industrial Plastics, 2009).

\begin{tabular}{ccccc}
\hline Piping & Material & $\begin{array}{c}\text { Thermal conduct- } \\
\text { ivity }(\mathrm{W} / \mathrm{mK})\end{array}$ & $\begin{array}{c}\text { Cost per metre } \\
(R)\end{array}$ & Durability \\
\hline Steel & Carbon Steel & 54 & 15 & Subject to rust \\
\hline Copper & Copper & 401 & 60 & Excellent \\
PEX & Cross-linked high-density pol- & 0.51 & 12 & Good \\
& yethylene & & 10 & Good \\
CPVC & Chlorinated polyvinyl chloride & 0.14 & 9.90 & Good \\
PE & Polyethylene & 0.38 & 12.50 & Good \\
\hline
\end{tabular}

Table 2: Conductivity and cost for different heat transfer fluids.

\begin{tabular}{ccccc}
\hline HTF & $\begin{array}{c}\text { Conductivity } \\
(\mathrm{W} / \mathrm{mK})\end{array}$ & Cost per litre & $\begin{array}{c}\text { Heat storage capacity } \\
\text { (specific heat) }(\mathrm{J} / \mathrm{kgK})\end{array}$ \\
\hline 1 & 0.609 & $\mathrm{R} 0.02$ & 4182 \\
2 & Water & 0.14 & $\mathrm{R} 70$ & 2500 \\
3 & Propylene glycol & Glycerine & R40 & 2430 \\
4 & Hydrocarbon oils & 0.285 & $\mathrm{R} 18$ & $1670-2500$ \\
5 & Silicones & 0.099 & $\mathrm{R} 50$ & $750-1500$ \\
\hline
\end{tabular}

\subsection{Choice of materials and sizing}

\subsubsection{Piping}

The properties of common tubing materials - thermal conductivity, cost and durability - that can be used for the grid absorber system are given in Table 1. The collector cost efficiency depends mostly on the area of the absorber piping. This suggests that one material should not simply be chosen over another for its conductivity. An experiment carried out indicated that the different thermal conductivity of materials does not have a significant impact on the eventual collector thermal efficiency (Ariyawiriyanan et al., 2013). As reflected in Table 1, polyethylene black piping, as generally available in South African hardware stores (see Figure 5), seems to offer a very good choice, given its thermal conductivity versus its low cost of construction per square metre, as well as durability.

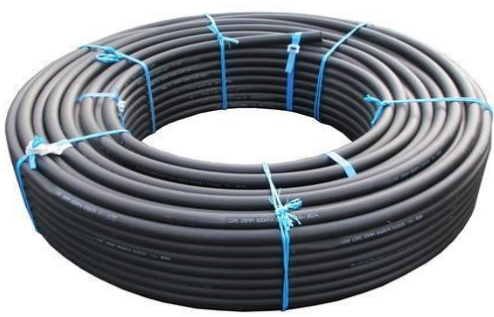

Figure 5: Standard polyethylene black piping (Indiamart, 2020)

\subsubsection{The Baseplate}

The commonly available cheap IBR galvanised steel plating, was used as a base plate to mount and posi- tion the series-connected polyethylene pipe in grooves and on top of the crest. This plate has the advantage of incorporated grooves and crests which can advantageously used to reflect and focus solar incident light to preferred areas of absorption above the plate (Figure 6). It can, further, be painted silver to increase the reflection capability.

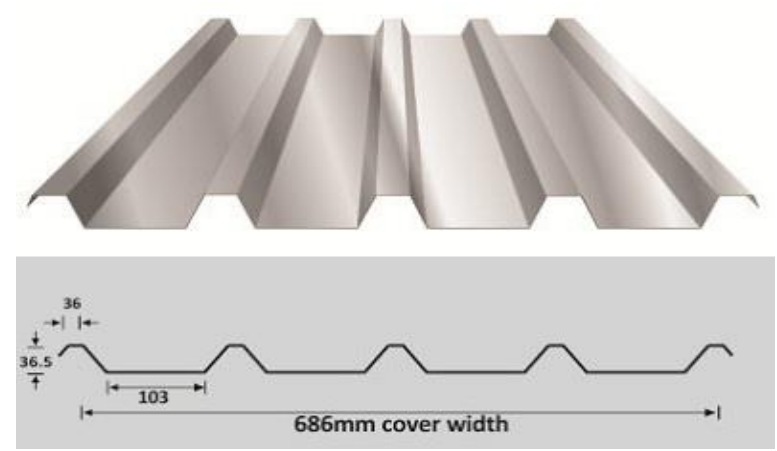

Figure 6: Inverted box rib galvanised steel plating (Masters, 2019)

\subsubsection{Choice of the heat transfer fluid}

Water is the cheapest of all the HTFs shown in Table 2 , is non-toxic, has a high specific heat capacity, has low viscosity, and is also easy to pump. For these characteristics, unmatched by the alternatives, water was selected as the best HTF to be used in the solar heat collector.

\subsection{Optimising the collector efficiency ( $(\mathrm{)})$}

The performance of a collector is denoted by its efficiency, $\eta$, given as the ratio of heat output from the 
collector and the amount of irradiation striking the surface of the collector absorber. Riffat et al. (2005) state that this measure of performance will vary with several external parameters, including global solar irradiation $\mathrm{I}_{\mathrm{n}}$, ambient temperature $\mathrm{T}_{\mathrm{a}}$, cooling fluid inlet temperature $\mathrm{T}_{\mathrm{o}}$, and mass flow rate $m$.

From Struckmann (2008), the thermal efficiency of a flat solar collector is given by:

$$
\eta=\frac{\int Q_{u} d t}{A_{C} \int I_{T} d t}
$$

The instantaneous thermal efficiency of the collector is given by:

$$
\mathrm{\eta}=\frac{Q_{u}}{A_{C} \times I_{T}}
$$

where $Q_{u}$ is the useful energy; $A_{c}$ is the collector area $\left(\mathrm{m}^{2}\right)$; and $\mathrm{I}_{\mathrm{T}}$ is solar irradiation in the collector plane $\left(\mathrm{W} / \mathrm{m}^{2}\right)$.

$$
\mathrm{Qu}_{\mathrm{u}}=\bar{m} \mathrm{C} \triangle \mathrm{T}
$$

where $\bar{m}$ - mass flow rate of HTF $(\mathrm{kg} / \mathrm{s}) L / \mathrm{min}=$ $\frac{L}{60} \mathrm{~kg} / \mathrm{s}$; and $\mathrm{C}$ is the specific heat of the heat transfer fluid (Water $=4186 \mathrm{~J} / \mathrm{kg} \mathrm{K}$ ).

$$
\triangle \mathrm{T}=\left|\left(\mathrm{T}_{\text {out }}-\mathrm{T}_{\text {in }}\right)\right|
$$

where $\mathrm{T}_{\text {out }}$ is the hot water out of the collector; and $\mathrm{T}_{\text {in }}$ is the cold water into the collector (Ariyawiriyanan et al., 2013).

\subsection{Grid-type versus series-type circulation}

The greater the total length of high-temperature pipe, the larger is the heat loss area (A), resulting in high heat losses. If the total length of pipe at high temperature is short, compared to the grid solar water heater total length, the heat loss area is minimised, resulting in reduced total heat losses. A series-connected tube system is preferred to a parallel/grid tube system because the hydraulic flow can be maximised by using a pump in series, allowing the storage tank to be positioned at any level above or below the collector (see Figure 7).

\subsection{Calculating heat transfer to the storage tank and sizing of the system}

Assuming that no heat losses are incurred and the temperature of the water rises from an ambient temperature of $20{ }^{\circ} \mathrm{C}$ to $70{ }^{\circ} \mathrm{C}$ from 09.00 to 14.00 of each day, then

$$
Q=m C_{p} \Delta T
$$

The predicted idealistic heat transfer per day is calculated using Equation 5 (see Figure 8).

The predicted real heat TE per day (predicted idealistic heat transfer minus losses

The predicted idealistic heat transfer per day, with predicted calculated heat losses as calculated by the simulation software as developed here, is shown in Figure 8.

\section{Predictive modelling for different positions and configurations of the polyethylene grid.}

The design and analysis of different collector designs, using different departure points in terms of piping layout and piping density are considered. Some estimates of the absorption efficiency for the entire piping reflector configuration are derived. All the designs were laid on the same size IBR steel plating and tested under the same weather conditions, for comparison of thermal efficiency and cost of construction, to eventually choose the most efficient design. The adopted design and configuration was one $25 \mathrm{~mm}$ pipe in a groove and one on top of the crest of the IBR steel plating (see Figure 13); hence, this was the design modelled.

\subsection{Analysis of the approximated fraction energy absorption $/ \mathrm{m}^{2}$ for adopted design $(25 \mathrm{~mm}$ piping) as a function of solar incident angle (time of day)}

Figures 9 to 12 show the approximated fractional energy absorbed by the pipes per square metre with different incident angles $\left(\ominus_{\mathrm{i}}\right)$.

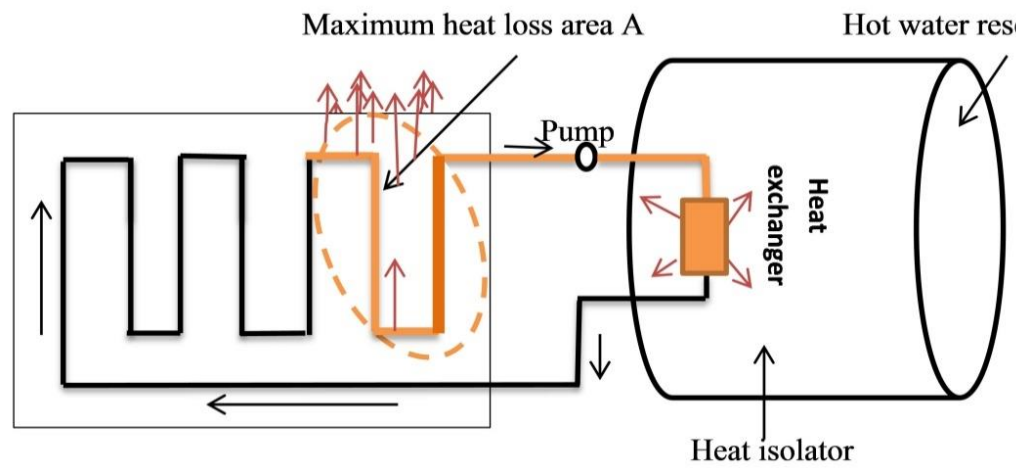

Figure 7: Heat loss of series tube solar water heater collector. 


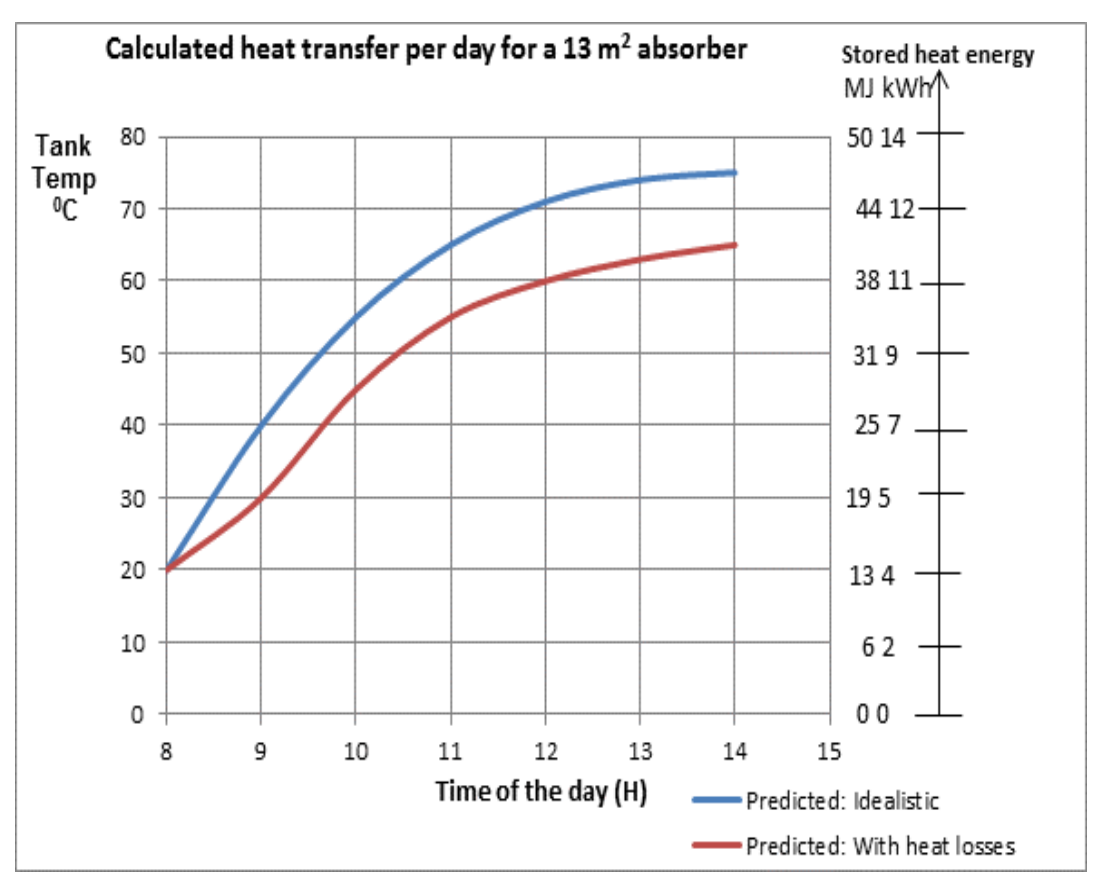

Figure 8: Predicted idealistic and predicted absorption with heat losses for a $13 \mathrm{~m}^{2}$ heat absorber.

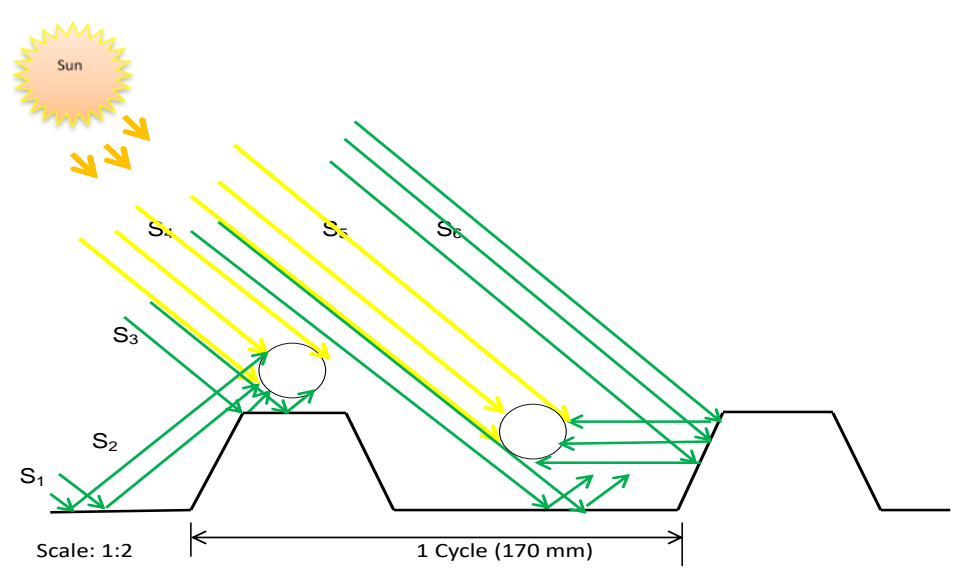

Figure 9: $25 \mathrm{~mm}$ piping: $\theta_{\mathrm{i}}=-45^{0}$.

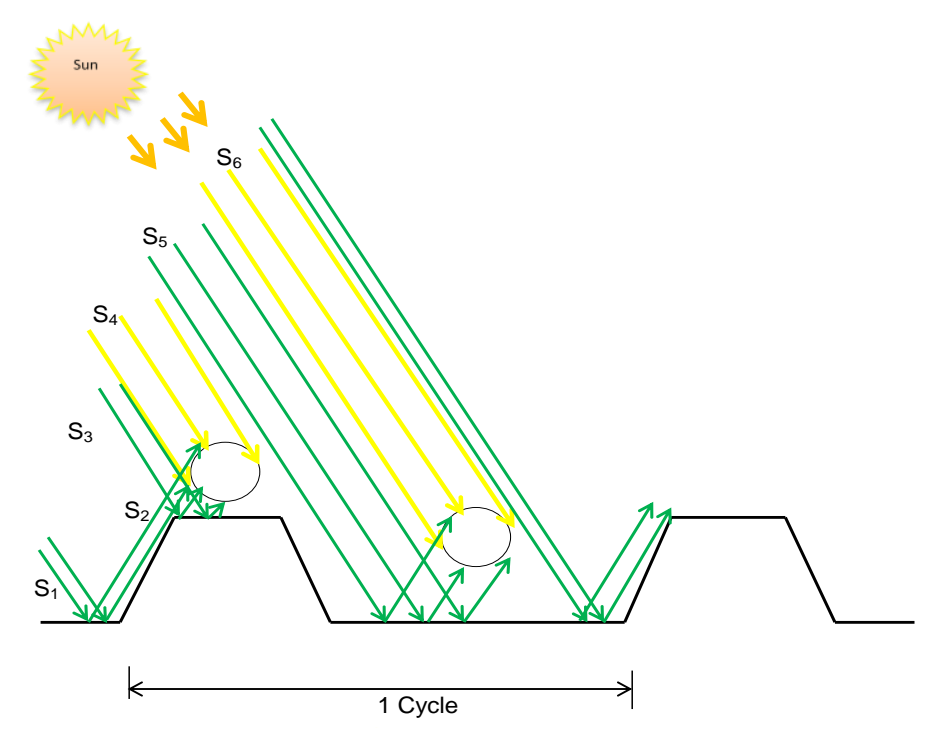

Figure 10: $25 \mathrm{~mm}$ piping: $\theta_{i}=-30^{\circ}$. 


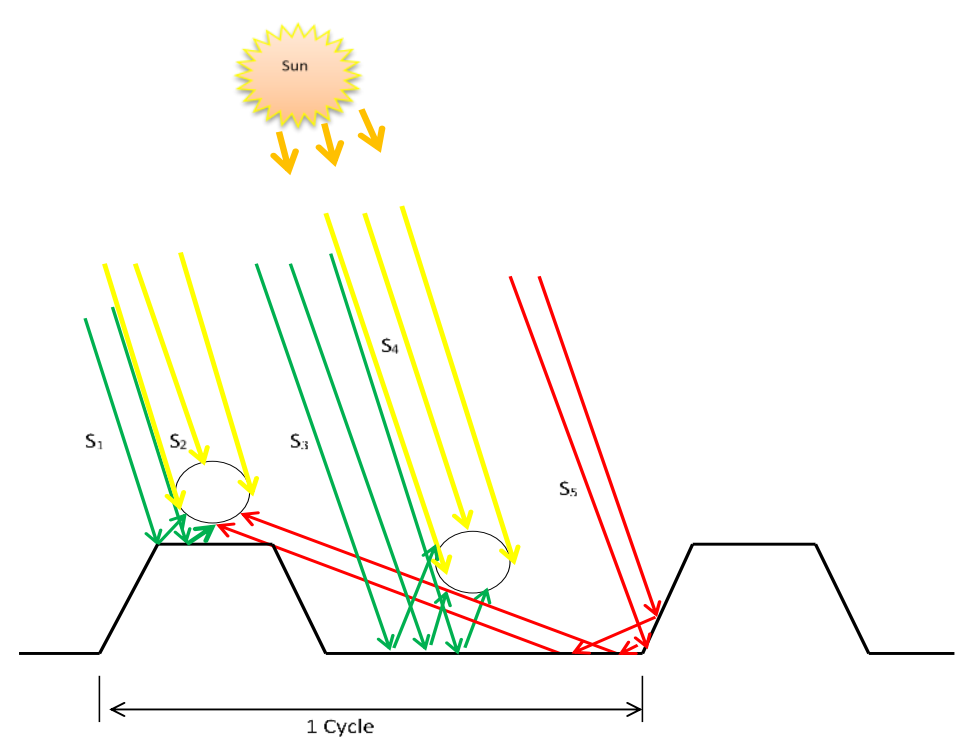

Figure 11: $25 \mathrm{~mm}$ piping: $\theta_{i}=-15^{\circ}$.

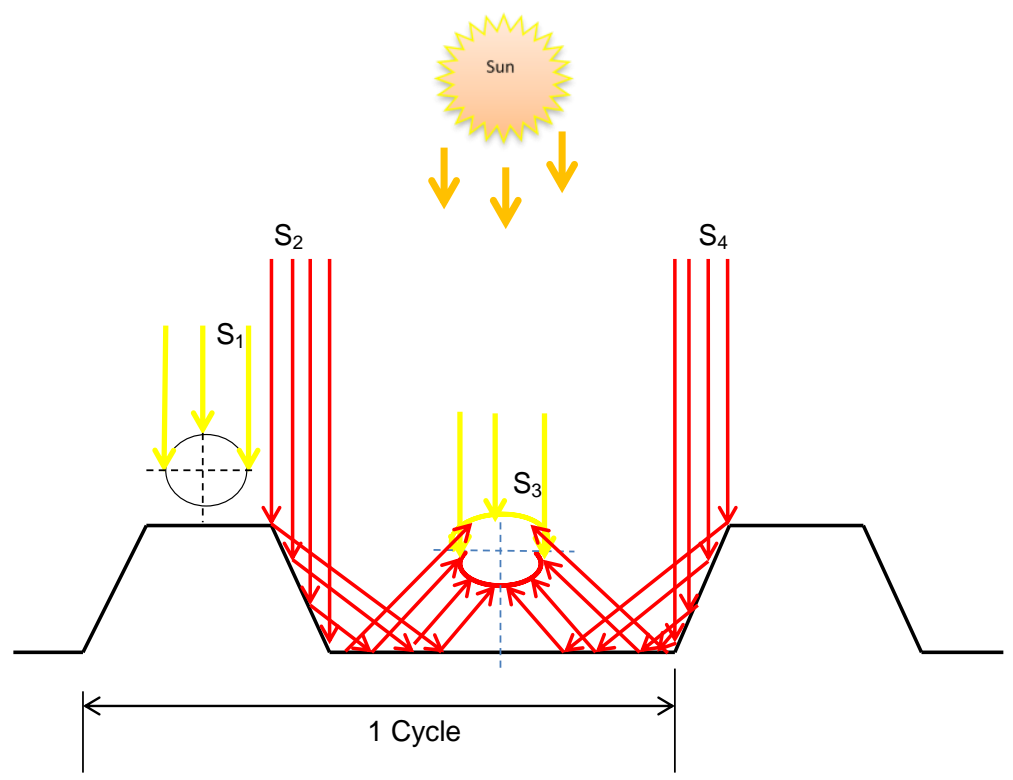

Figure 12: $25 \mathrm{~mm}$ piping: $\theta_{i}=0^{0}$.

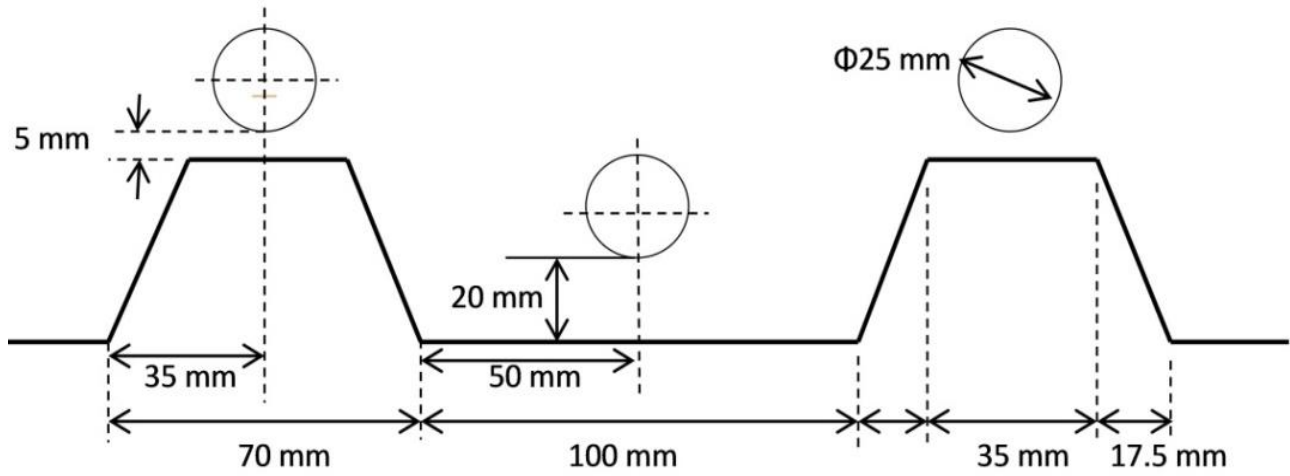

Figure 13: Final design layout. 


\subsection{The final choice}

From all the analysed designs, the design shown (drawn to scale) in Figure 13 was adopted as the lowest-cost and best-compensated design in terms of efficiency.

As performed from detailed modelling and calculations not shown here, an efficiency index versus incidence angles of the sun's rays was derived, as shown in Figure 14. The index shows that relatively good thermal absorption characteristics are derived for the finally designed reflective plate absorber from $-25^{0}$ to $+25^{0}$ incidence angle of solar rays.

Figure 15 shows the final design as was implemented in an outdoor area at the UNISA CSET campus, incorporating predictive modelling Design 3 with a heat transfer system coupled to a conventional 150-litre household geyser.

\section{Experimental analyses}

The experimental procedure involved in implementing the test system was the following:

1. Doing predictive modelling, as in Section 3, with various pipe diameter sections and different pipe arrangements in the trough.

2. Selecting the best low-cost versus efficiency system for experimental testing.

3. Testing the thermal energy absorbed in the geyser with time-lapse in the day. This could easily be determined by using the volume of water in the tank, measuring the temperature in the water every hour and plotting these with suitable statistical analysis software.

4. The procedure, as in (3), was repeated for different flow rates of circulation. According to the mathematical modelling used, the energy stored in the geyser tank should rise as a function of

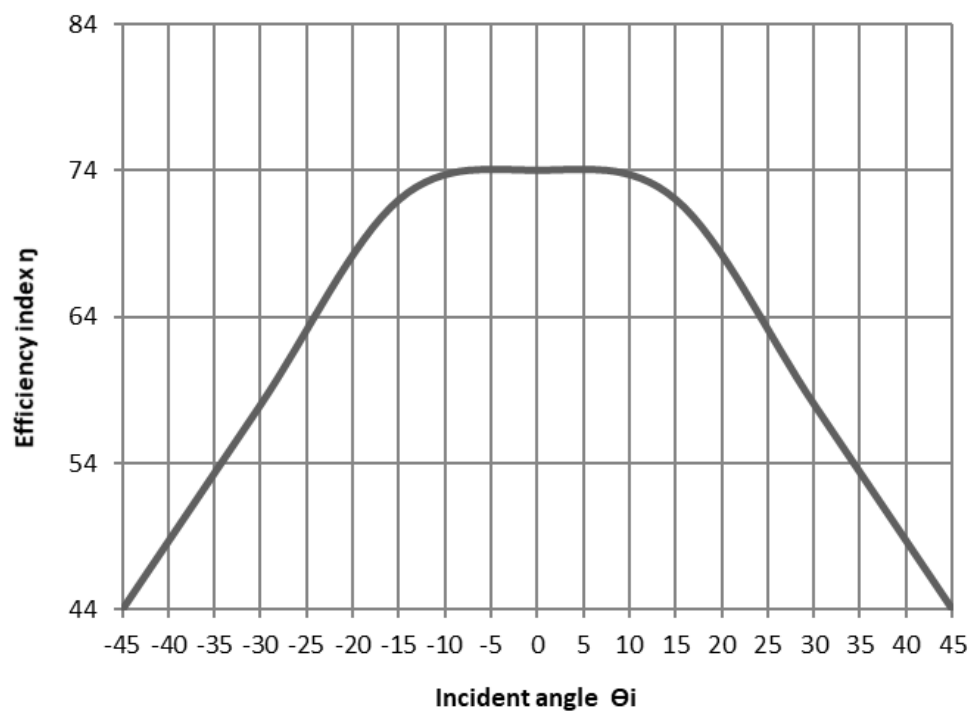

Figure 14: Efficiency index as a function of solar incidence angle.

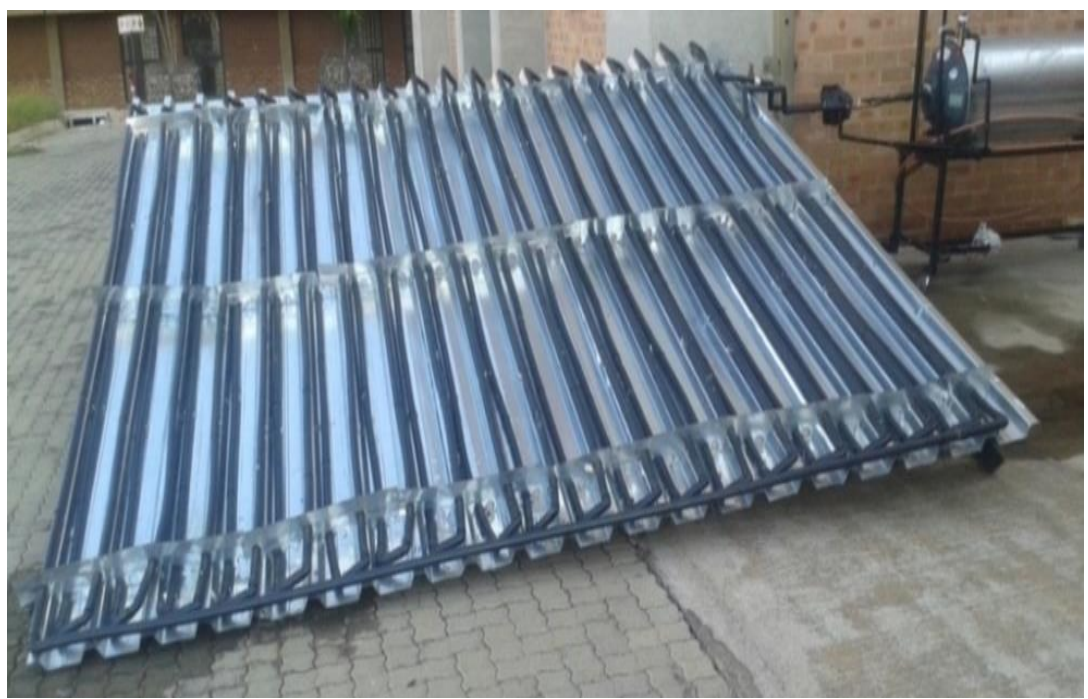

Figure 15: The developed low-cost solar water heater system at UNISA Florida Research Laboratory (Snyman, 2019). 
flow rate and decrease again when the flow rate is too high and excessive heat is circulated back into the absorber.

5. The procedure in (3) was repeated for different heat exchanger configurations, with final analyses of circulation into the tank without using a heat exchanger. In such a case, the pressure in the circulation piping would be the same as the pressure in the city grid supply and no isolation of pressures would be present. In the latter case, a water pressure regulator could be placed in the circulation line, albeit at an increase in the cost and complexity of the system.

Three reflective thermal energy absorbers were eventually tested and analysed, using the above procedure and combinations of the technology, as described in sections 2 and 3 . A system of a reflective plate absorber, $3 \times 4 \mathrm{~m}$ in area, was connected with a copper coil heat exchanger in a 150-litre capacity conventional commercially bought solar geyser, nomenclature Prototype 1. A system of a reflective plate absorber with an area of $3 \times 4 \mathrm{~m}$ connected with a commercially bought flat plate sheet absorber of $2 \mathrm{~m}^{2}$ and 150-litre capacity conventional commercially bought solar geyser, connected with a heat exchanger copper coil inside the geyser tank as shown in Figure 2, nomenclature as Prototype 2 . A system of a reflective plate absorber with an area of $3 \times 4 \mathrm{~m}$ connected with a commercially bought flat plate sheet absorber of $2 \mathrm{~m}^{2}$ but connected directly (without a heat exchanger) with the commercially 150-litre geyser tank, nomenclature as Prototype 3.

\section{Experimental results}

The following paragraphs present a synopsis of the major experimental observations that were obtained
Ample data is presented, as collected and subsequently plotted graphically.

\subsection{Energy loss in the geyser tank (reservoir) during the night}

The graph in Figure 16 shows the variation of the temperature of water in the geyser tank from 3:00 p.m. until 9:00 a.m. the next day. The results show that heat retention is good during the day, with not too large a loss during the night is about $400 \mathrm{Wh}$.

\subsection{Prototype 1: The collector coupled to the tank through a heat exchanger}

In this test the collector pipes were connected to those of a heat exchanger, forming a closed loop (see Figure 17a). The DC circulating pump was pumping HTF at a maximum flow rate of 7 litres per minute. The energy stored in the tank for the entire period was of the order of $0.54 \mathrm{kWh}$.

Installing a stronger pump raised the pump flow rate to 15 litres per minute, and a considerable improvement in the stored energy in the geyser tank was noticed, of the order of $1.5 \mathrm{kWh}$ (see Figure 17b).

The change in temperature $\Delta \mathrm{T}_{1}=\mathrm{T}_{\max }-\mathrm{T}_{\min }=$ $35^{\circ} \mathrm{C}-20{ }^{\circ} \mathrm{C}=15^{\circ} \mathrm{C}$.

\subsection{Prototype 2: The collector connected with a standard metal sheet collector and then coupled with the heat exchanger}

The collector was connected to in series with a hybrid sheet collector, using a strong DC pump to circulate the HTF at a high flow rate. The system was run from 9:00 a.m. to 3:00 p.m. The change in temperature $\triangle \mathrm{T}_{2}=\mathrm{T}_{\max }-\mathrm{T}_{\min }=48{ }^{\circ} \mathrm{C}-19{ }^{\circ} \mathrm{C}=29{ }^{\circ} \mathrm{C}$. The data plots in Figure 18 show the trend that was observed.

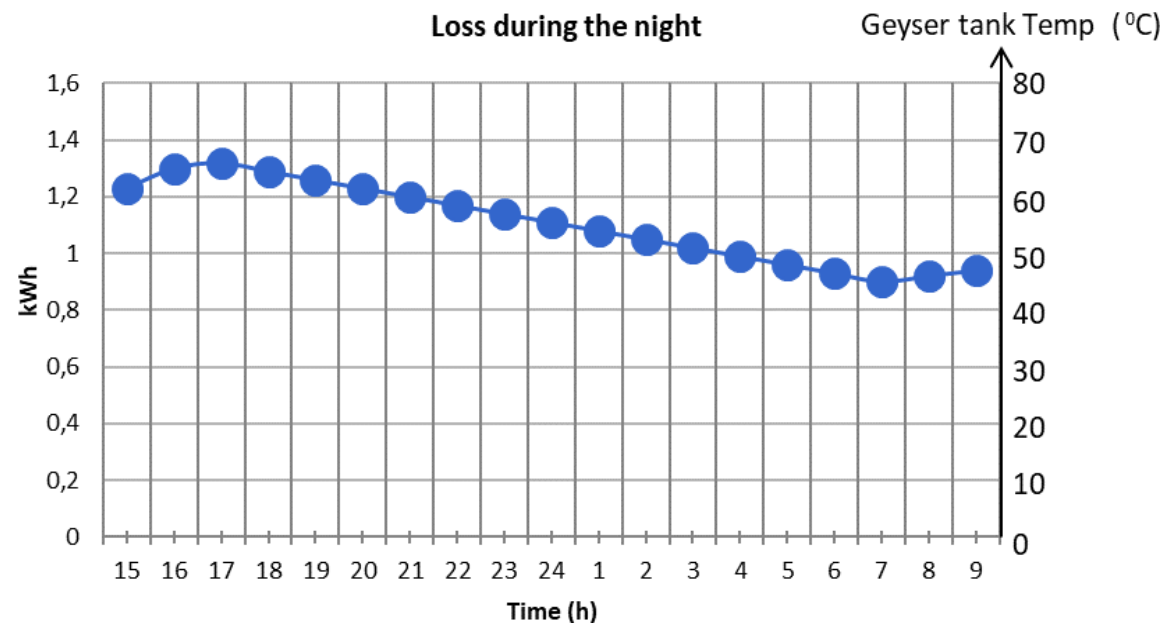

Figure 16: Energy loss in the geyser tank (reservoir) during the night, ambient temperature average $10^{\circ} \mathrm{C}$. 


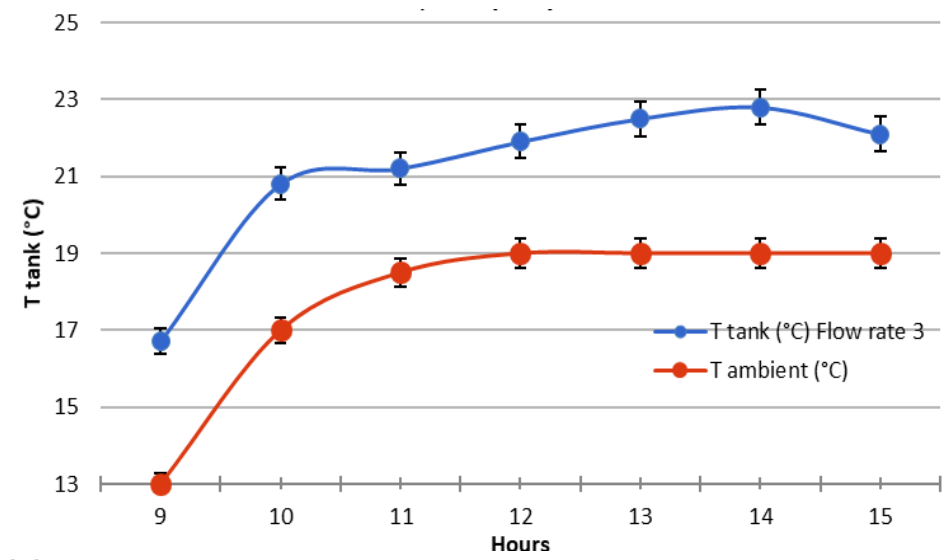

Figure 17(a): Prototype 1: Thermal measures with pump flow rate 7 litres per minute.

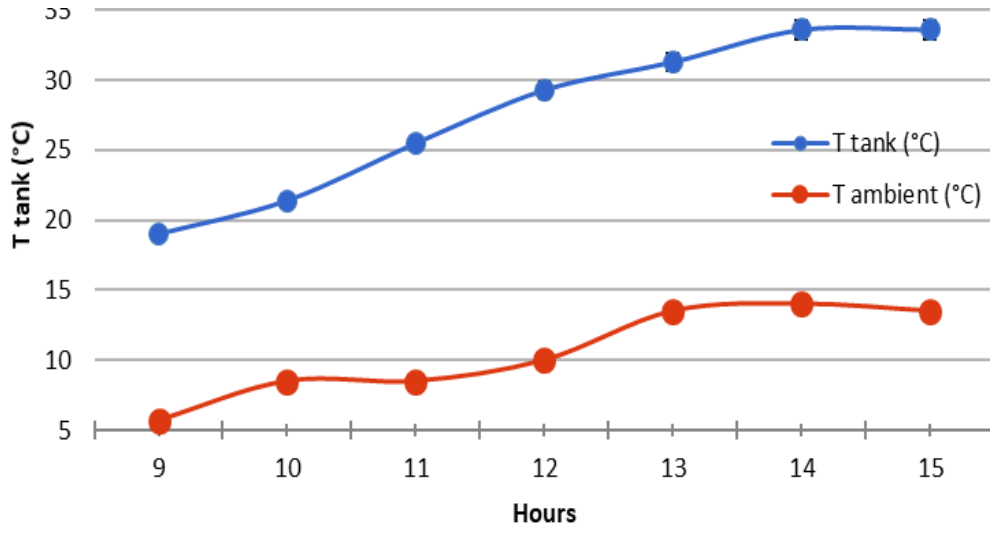

Figure 17(b): Prototype 1: Thermal measures with DC pump flow rate 15 litres per minute.

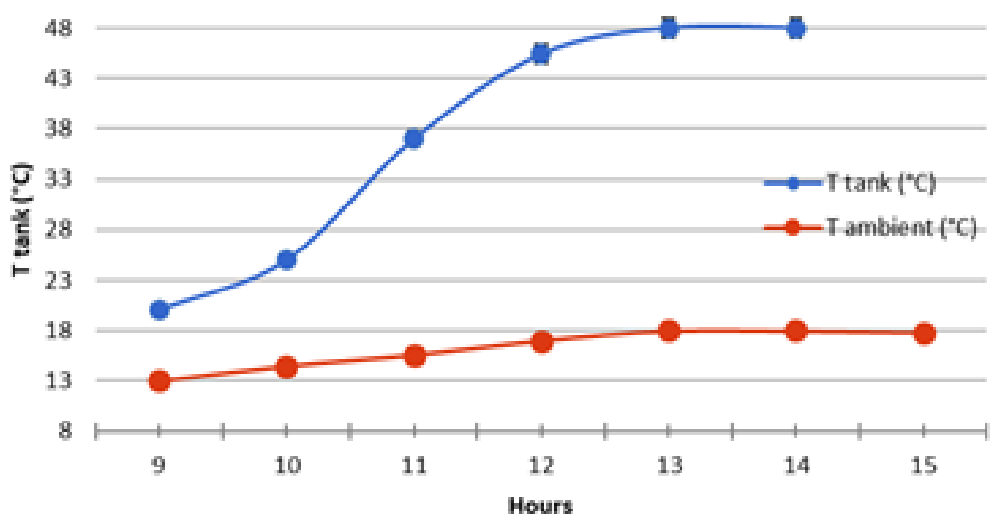

Figure 18: Prototype 2: Thermal measures with DC pump (18/07/2018).

\subsection{Prototype 3: The Collector plus hybrid sheet collector without a heat exchanger}

The collector plus hybrid sheet collector where the heat exchanger was removed (see Figure 19). The heated water in the tank runs through the collector pipes to collect heat energy. A strong DC pump was used to circulate the water at a high flow rate. The system was run from 10:00 a.m. to 2:00 p.m. The modification of the prototype managed to increase the efficiency of the system significantly during the four-hour time period of test (from $\triangle T_{1}=15{ }^{\circ} \mathrm{C}$ to $\triangle \mathrm{T}_{3}=42^{\circ} \mathrm{C}$ ). The change in temperature $\Delta \mathrm{T}_{3}=\mathrm{T}_{\max }$ $-\mathrm{T}_{\min }=62{ }^{\circ} \mathrm{C}-20^{\circ} \mathrm{C}=42{ }^{\circ} \mathrm{C}$. Figure 19 shows the trend that was observed.

\subsection{Comparison of the theoretically predicted} values and real experimentally measured results for Prototypes 2 and 3.

The realised $\mathrm{kWh}$ as stored for the different prototype systems, Prototype 2 and Prototype 3 , as elucidated above, are respectively shown in Figure 20 and Figure 21. 


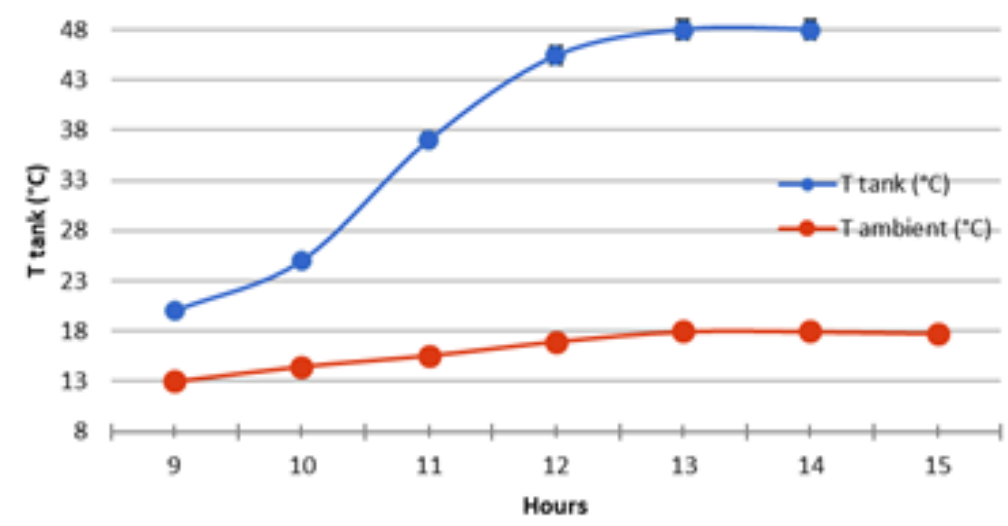

Figure 19: Prototype 3: Thermal measures with DC pump.

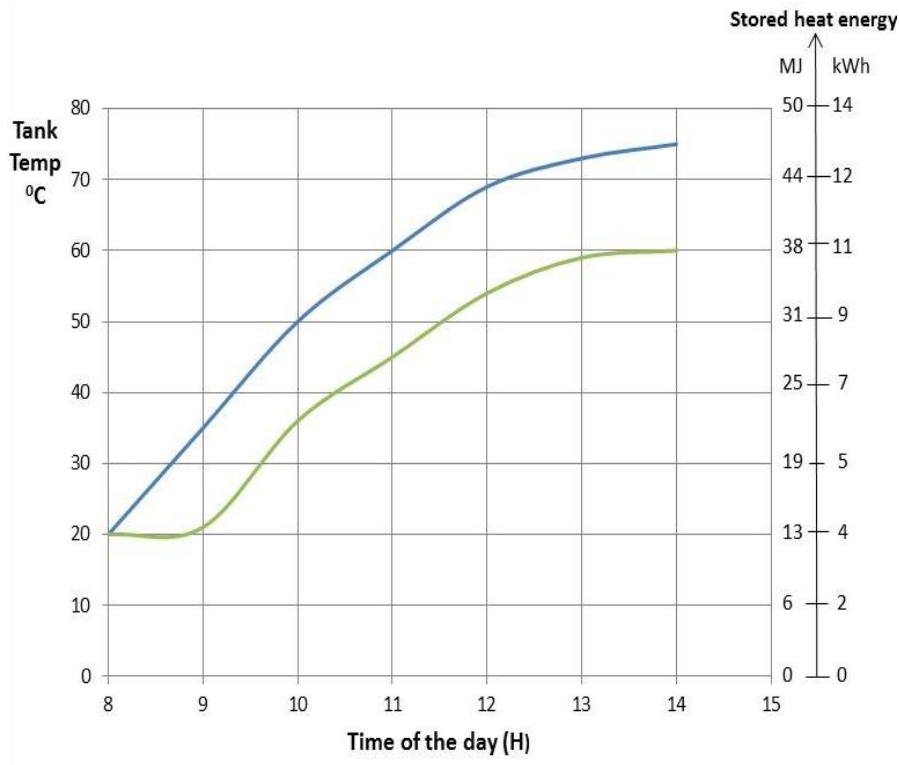

- Predicted Ideal —Experimenatal

Figure 20: Prototype 2: Predicted ideal and experimental value curves.

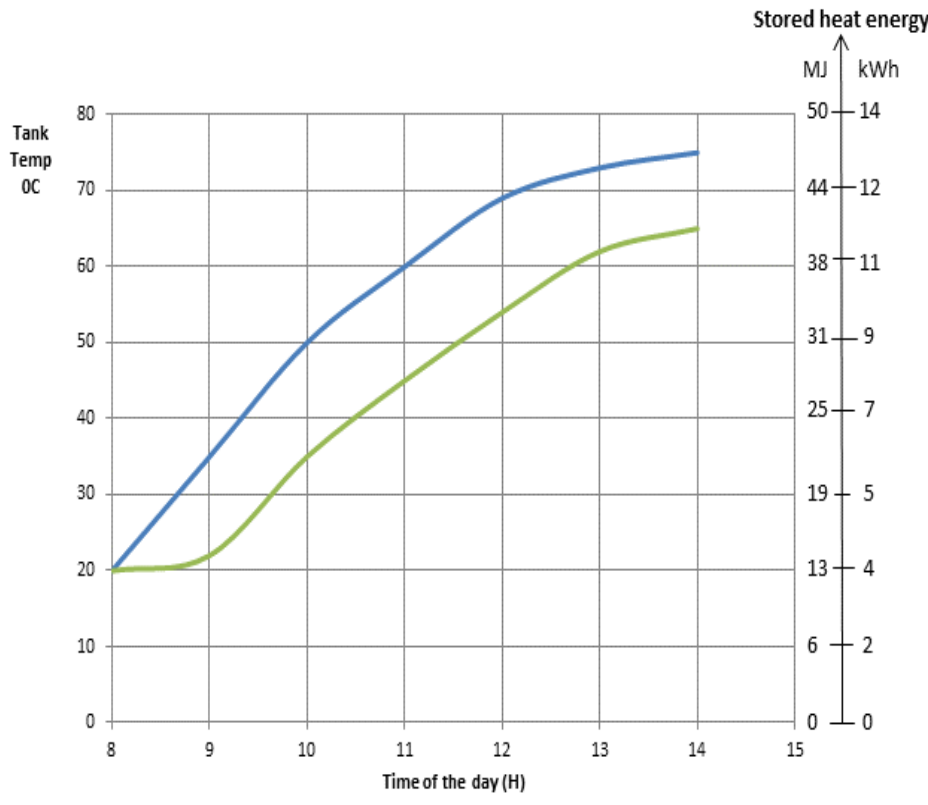

-Predicted Ideal —Experimenatal

Figure 21: Prototype 3: Predicted ideal and experimental value curves. 
Prototype 3, with no heat exchanger, showed higher experimental values in terms of $\mathrm{kWh}$ stored over a certain period of time than Prototype 2, which uses a thin diameter coil heat exchanger. The heat exchanger introduced some resistance to the flow of HTF, reducing heat transfer to the geyser tank. However, a high-pressure/low-pressure separation as implemented by us and explained in Section 1 is preferred, and therefore Prototype 2 was the preferred implementation system.

The efficiencies for the respective systems were calculated as of the order of $40 \%$ for Prototype 1 system, of the order of $60 \%$ for Prototype 2 system and of the order of $70 \%$ for the Prototype 3 system, using theory as outlined in Section 2.5 above.

\section{Cost-yield analyses for the prototypes' experimental results \\ 6.1 Total cost of the system}

The total cost of the solar geyser system was calculated as the total cost of materials used to build part A (geyser tank) and part B (solar heat collector) .

Prototype 3 (Without a heat exchanger):

Total cost $=$ Part A + Part B + Labour cost $=$ R5 461

+ R6 $715.92+\mathrm{R} 1500=\mathrm{R} 13676.92$

Prototype 2 (With a heat exchanger):

Total cost $=\mathrm{R} 13676.92+\mathrm{R} 750=\mathrm{R} 14426.92$

\subsection{Savings for the household user}

The national average daily consumption for a typical household (4-5 people), according to Eskom, is about $30 \mathrm{kWh}$. Using the Eskom Tariffs \& Charges Booklet 2019/2020, the charge per kWh is 153.90 cents = R1.54 (Eskom, 2019: 25):

Total electricity cost per day = 30 kWh @ R1.54 $=\mathrm{R} 46.20$.

Total electricity cost per month $=30$ days $\mathrm{x}$ R46.20 = R1 386 per month.

In general, hot water accounts for approximately $60 \%$ of the total electrical energy consumed:

$60 \%$ of R1 $386=$ R831.60, and this should be the estimated saving per month.

\subsection{Payback period}

The payback period is the time required to recoup the funds invested in a solar geyser and is calculated as follows:

Payback period in months $=$
Payback period using Prototype 2 (with a heat exchanger coil) was calculated as follows:

Payback period in months =

$\frac{\text { Purchase and installation price }}{\text { monthly savings }}=\frac{\mathrm{R} 14426.91}{831.60}=18$ months

Payback period using prototype 3 (without a heat exchanger coil) was calculated as follows:

Payback period in months $=$

$\frac{\text { Purchase and installation price }}{\text { monthly savings }}=\frac{\mathrm{R} 13676.92}{831.60}=17$ months

\subsection{Savings over the product lifetime}

The product lifetime of the constructed thermal collector systems is estimated to be approximately ten years (see Table 3). The designed adaptive solar geyser system has a fixed price (purchase and installation price), no need for electrical power except during prolonged periods of cloudy weather, and no monthly running costs once installed.

If there is included an estimated 6\% tariff increase per annum, compounded annually (on the current energy cost of R1.54 per kWh), the savings in ten years will rise to approximately R200 000 .

\subsection{Comparison of Prototypes 2 and 3 with the systems commonly found on the South African market.}

The built prototypes were tested under different weather conditions of South Africa and the results were compared with the commercial water heating systems commonly found on the market in South Africa. Table 4 and the graphs below give the comparison of different solar water heating systems.

\subsection{Energy cost (R/kWh) of the five different solar water heating systems, projected for summer}

As Figure 22 shows, the cost of energy of Prototype 3 is very low (R0.25 per $\mathrm{kWh}$ ) compared with the other systems, which range to nearly R1.00 per kWh and more.

\section{Conclusions}

A simple, efficient, and reliable solar water heating system has been developed from low-cost and readily available materials in South African builders' hardware shops. The cost of the newly developed reflective plate collector is about one-third of the purchase price of commercially available solar geyser hot water collector systems in South Africa.

Prototype 2 is selected as a preferred and most viable product for the South African market due to the advantages of using a heat exchanger coil, as de- 
Table 3: Estimated savings of adaptive solar geysers.

\begin{tabular}{|c|c|c|c|c|c|c|c|c|c|}
\hline & \multirow[t]{2}{*}{$\begin{array}{l}\text { Purchase and instal- } \\
\quad \text { lation cost }\end{array}$} & \multicolumn{7}{|c|}{$\begin{array}{c}\text { Electricity cost (5\% escalation per year) } \\
\text { Months/years }\end{array}$} & \multirow[t]{3}{*}{$\begin{array}{l}\text { Cost per } \\
\quad k W h\end{array}$} \\
\hline & & $\begin{array}{l}10 \\
\text { months }\end{array}$ & $\begin{array}{c}12 \\
\text { months }\end{array}$ & $\begin{array}{c}13 \\
\text { months }\end{array}$ & $\begin{array}{c}14 \\
\text { months }\end{array}$ & $\begin{array}{c}18 \\
\text { months }\end{array}$ & 5 years & 10 years & \\
\hline $\begin{array}{c}\text { Electric geyser } \\
\text { 150L, 220V, } \\
\text { 3kW (Plump- } \\
\text { link, 2020) }\end{array}$ & R3 500 & R11 816 & R13 479 & R14 352 & R15 226 & R18 718 & R64 020 & R164 288 & \\
\hline \multirow{2}{*}{$\begin{array}{l}\text { Adaptive solar } \\
\quad \text { geyser }\end{array}$} & Prototype 2 R13 677 & None & None & None & None & None & None & None & \\
\hline & Prototype 3 R14 427 & None & None & None & None & None & None & None & \\
\hline \multirow{2}{*}{$\begin{array}{l}\text { Corresponding } \\
\text { savings }\end{array}$} & Prototype 2 R10 177 & R1861 & R198 & R0 & +R1 549 & +R5 041 & +R50343 & +R150611 & $\mathrm{R} 0.29$ \\
\hline & Prototype 3 R10 927 & R2611 & R948 & R75 & R0 & +R4 291 & +R49593 & $+\mathrm{R} 149851$ & $\mathrm{R} 0.25$ \\
\hline
\end{tabular}

Table 4: Comparison of the prototypes with different solar water heating systems on the market.

\begin{tabular}{lcccccc}
\hline \multicolumn{1}{c}{ Solar water heater } & Persons & $\begin{array}{c}\text { Price } \\
(R)\end{array}$ & $\begin{array}{c}\text { Energy } \\
\text { cost } \\
\text { R/kWh }\end{array}$ & $\begin{array}{c}\text { Deemed } \\
k W h / \text { day }\end{array}$ & $\begin{array}{c}\text { Payback } \\
\text { time } \\
\text { (months) }\end{array}$ & $\begin{array}{c}10 \text { year } \\
\text { savings } \\
(R)\end{array}$ \\
\hline $\begin{array}{l}\text { 1. Natural circulation system } \\
\text { (Flat plate 150L CCT) }\end{array}$ & $3-4$ & 21500 & $\mathrm{R} 1.08$ & 5.50 & 40 & 86242 \\
\hline $\begin{array}{l}\text { 2. Forced circulation system } \\
\text { (SIP 30EVT 150L) }\end{array}$ & $3-4$ & 24500 & $\mathrm{R} 0.89$ & 7.60 & 33 & 88700 \\
\hline $\begin{array}{l}\text { 3. Evacuated Vacuum Tube } \\
\text { system (150L CCT EVT) }\end{array}$ & $3-4$ & 23500 & $\mathrm{R} 0.94$ & 6.90 & 30 & 96332 \\
\hline $\begin{array}{l}\text { 4. Prototype 2 (Collector \& } \\
\text { hybrid sheet with heat } \\
\text { exchanger) }\end{array}$ & $3-4$ & 14427 & $\mathrm{R} 0.29$ & 13.79 & 13 & 150611 \\
\hline $\begin{array}{l}\text { 5. Prototype 3 (Collector \& } \\
\text { hybrid sheet without heat } \\
\text { exchanger) }\end{array}$ & $3-4$ & 13677 & $\mathrm{R} 0.25$ & 15.29 & 14 & 149861 \\
\hline
\end{tabular}

Commercial systems on the market

Adaptive solar heat geyser

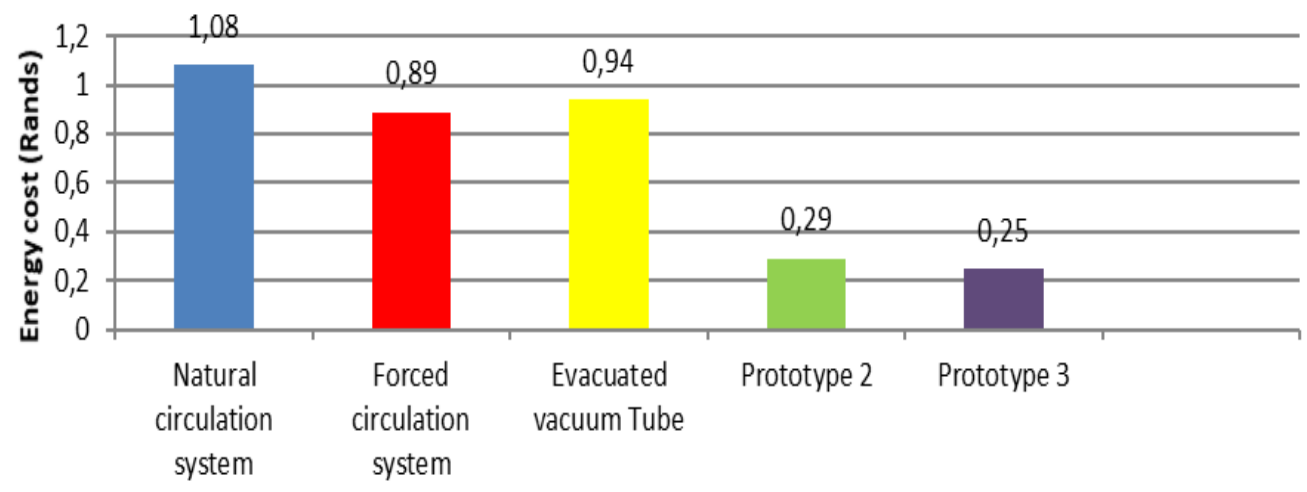

Figure 22: Energy cost of different solar water heating systems. 
scribed in section 5.5.4, which tends to outweigh the advantages associated with Prototype 3 . The utilisation of the prototype as developed in this study can lead to extensive savings for South African households. It can result in substantial savings in monthly electricity bills for households at all income levels.

These systems can also make substantial contributions towards reducing the traditional use of coal energy, oil, and gas resources in South Africa. This could also assist to greatly reduce the emission of greenhouse gases in the country.

It is anticipated that the technology and designs as developed through the study can create many new business opportunities in South Africa (as well as in Africa as a whole), both in the urban and rural environments, from manufacturing to installation, to repair and maintenance. The construction of the various systems illustrated in this study show that the skills necessary to construct and manufacture them are low, and could be implemented to be labour-intensive, providing many new job opportunities.

\section{Author contributions}

This project was completed as a Masters Degree in Technolgiae at the University of South Africa. Fanos Mutizhongo was registered at the Department of Electrical Engineering and was working under the supervision of Lukas Snyman who currently is with the Institute for Nanotechnology and Water Sustainability. At completion of his studies he was also an associate of the Institute. Kevin Jalet was an intern from ISIEE France to the Department of Electrical Engineering during 2019 and during the initial phases of the project.

\section{Acknowledgments}

The authors would like to thank the Department of Electrical and Mining Engineering of the College of Science Engineering and Technology of the University of South Africa (UNISA Florida) for providing general laboratory space and the College security for granting us space on their grounds in order to perform extensive experimental construction and experimental tests. The experimental and technical contributions of F. Twite, co-student, toward compiling measurements and assisting in constructing the systems are gratefully acknowledged.

\section{Protection of Intellectual Properties}

The content of this article forms the subject of RSA Patent 2016/05297, RSA Patent 2009/03072, RSA Patent 2009/3071, PCT Patent Application WO/2018/09, PCT Patent Application WO/2017/008090, PCT Patent Application PCT/ZA2016/050021.0065, PCT Patent Application PCT/ZA2017/050084, and Provisional SA Patents 2012/1508 and 2016/07673 (Snyman, 2012 - 2018).

The intellectual property emanating from the study belongs to the University of South Africa. The intention is to make this technology available to the broader public and business sector of South Africa through appropriate licensing and local business creation actions, while a small portion of the wealth as may be generated will be channelled back to UNISA to promote further development actions. Interested investors, or commercialisers of the technology are referred to the Department of Technology Transfer and Commercialisation at UNISA main campus for negotiations and quotations in this regard. Blueprints of all technical drawings and of electronic circuitry and components can be obtained and negotiated from the same office,

\section{References}

Ariyawiriyanan,W., Meekaew, T., Yamphang, M., Tuenpusa, P., Boonwan, J., Euaphantasate, N., Muangchareon, P. and Chungpaibulpatan, S. 2013. Thermal efficiency of solar collector made from thermoplastics. Energy Procedia. 34: 500-505. doi:10.1016/j.egypro.2013.06.778.

Boxwell, M. 2018. Solar electricity handbook. Greenstream. Available from: http://www.solarelectricityhandbook.com/solar-irradiance.html [Accessed 2nd December 2019].

Chang, T. P. 2008. Study on the optimal tilt angle of solar collector according to different radiation types. International Journal of Applied Science and Engineering 6(2): 151-161. doi:10.1.1.512.5360.

Council for Scientific and Industrial Research (CSIR) 2016. Forecasts of electricity demand in South Africa (2014-2050) using the CSIR sectoral regression model. Available from: http://www.energy.gov.za/IRP/2016/IRP-AnnexureBDemand-forecasts-report.pdf

EMCO Industrial Plastics. 2009. The Thermal Conductivity of Common Tubing Materials Applied in a Solar Water Heater Collector. Available from: http://ascpro0.ascweb.org/archives/cd/2010/paper/CPRT192002010.pdf [Accessed 10th October 2019].

Eskom. 2019. Tariffs \& Charges Booklet 2019/2020. Available from: http://www.eskom.co.za/CustomerCare/TariffsAndCharges/Documents/2019_20\%20Tariff\%20Book\%20\%281\%20April\%202019\%20rev\%2001\%29.pdf [Accessed 20 April 2019].

Holme, P. A., Kusakana, K. and Numbi, B. P. 2019. A review of water heating technologies: An application to the South African context. Energy Reports 5(2019): 1-19. doi:10.1016/j.egyr.2018.10.013.

Hussein, A.K., Walunj, A. A. and Kolsi, L. 2016. Applications of nanotechnology to enhance the performance of the direct absorption solar collectors. Journal of Thermal Engineering 2(1): 529-540.

Indiamart. 2020. Drip Irrigation Pipes. Available from: https://www.indiamart.com/proddetail/40mm-hdpe-pipe11870970248.html [Accessed 7th August 2020] 
Jayakanth, J. J., Ramasubramanian, S., Chandrasekaran, M.and Manavalan, S. 2017.

Investigation of the solar water heater by using flat plate collector and evacuated tubes. IOP Conference Series: Materials Science Engineering 183( 012035). doi:10.1088/1757-899X/183/1/012035.

Juanico, L. E. and Di Lalla, N. 2013. A New Low-Cost Plastic Solar Collector. ISRN Renewable Energy 2013: 1-10. doi:10.1155/2013/102947.

Lenert, A., Nam, Y. and Wang, E. N. 2012. Heat Transfer Fluids. Annual Rev Heat Transfer 15 (15): 93-129.

Masters. 2019. Roofing Products. Available from: http://www.masters.co.zw/wp-content/uploads/2015/06/ibr300x212.jpg [Accessed 7th August 2020]

Mvuli-Gumbio, S. and Snyman, L. W. 2018. Developing a small photovoltaic power supply system with adaptive technologies for rural Africa: Design, cost and efficiency analyses. Journal of Energy in Southern Africa 29(4): 60-68. doi:10.17159/2413-3051/2018/v29i4a5399.

Northern Lights. 2014. Calculating the Angle of Solar Collector. Available from: https://www.solartubs.com/solar-collector-angle.html [Accessed 3rd December 2018].

Nshimyumuremyi, E. and Junqi, W. 2019. Thermal efficiency and cost analysis of solar water heater made in Rwanda. Global Journal of Engineering 37(3): 1147-1161. doi:10.1177/0144598718815240.

One Energy. 2019. You're burning your hard-earned cash if you haven't converted to a solar geyser. Available from: https://oneenergy.co.za/solar-water-heating-gives-you-a-25-roi/ [Accessed 11th September 2020].

Petterson, J. E. and Miers, R. J. 2010. The Thermal Conductivity of Common Tubing Materials Applied in a Solar Water Heater Collector. Available from: http://www.ascpro0.ascweb.org/archives/cd/2010/paper/CPRT192002010.pdf. [Accessed 5th August 2017].

Plumblink. 2020. Geysers. Available from: https://www.plumblink.co.za/geysers [Accessed 5th March 2021]

Riffat, S. B., Zhao, X. and Doherty, P. S. 2005. Developing a theoretical model to investigate thermal performance of a thin membrane heat-pipe solar collector. Applied Thermal Engineering 25: 899-915. doi:10.1016/j.applthermaleng.2004.08.010.

Shemelin, V. and Matuska, T. 2017 Detailed Modelling of Flat Plate Solar Collector with Vacuum Glazing. International Journal of Photoenergy 2017: 1-9. doi:10.1155/2017/1587592.

Singh, J. 2016. Ranking South African provinces based on MERRA 2D surface incident shortwave flux. Journal of Energy in Southern Africa 27(3): 50-57. doi:10.17159/2413-3051/2016/v27i3a1555.

Solar GIS. 2017. Solar resource maps for South Africa. Available from: https://solargis.com/maps-and-gis-data/download/south-africa [Accessed 22nd January 2019].

Twite, M. F., Snyman, L.W., De Koker, J. \& Yusuff, A. A. 2019. Development of a large-area, a low-cost solar water-heating system for South Africa with a high thermal energy collection capacity. Journal of Energy in Southern Africa. 30(1): 49-59. doi:10.17159/2413-3051/2019/v30i1a5226.

UberSolar. 2018. Prices. Available from: http://ubersolar.co.za/prices-and-systems/ [Accessed 17th January 2020].

UberSolar. 2018. Performance. Available from: http://ubersolar.co.za/performance/ [Accessed 17th January 2020].

Ward, S. 2002. The Energy Book for Urban Development in South Africa. Noordhoek. 